Uluslararası Mühendislik

Cilt/Volume:12 Sayı/Issue:1 Ocak/January 2020

Araştırma Makalesi / Research Article

\title{
Production of Boric Acid from Microwave-Dehydrated Ulexite Waste by Oxalic Acid Solution Leaching
}

\author{
Feray Koçan $^{1 *}$ iD, Salih Uğur Bayça ${ }^{2}$ iD
}

${ }^{1}$ Celal Bayar University, Science and Arts Faculty, Chemistry Department, 45030 Muradiye, Manisa, TURKEY.

${ }^{2}$ Kirikkale University, Faculty of Engineering, Department of Metallurgy and Materials Engineering, 71450 Yahsihan, Kirikkale, TURKEY.

Başvuru / Received: 05/04/2019

Kabul / Accepted: 04/09/2019

Çevrimiçi Basım / Published Online: 04/1 1/2019

Son Versiyon/Final Version: 31/01/2020

\begin{abstract}
An investigation was made of the production of boric acid from microwave-dehydrated ulexite waste by leaching with oxalic acid solution. An ulexite waste sample was dehydrated in a domestic microwave oven, and then dissolved in oxalic solution at temperatures of between 25 and $70^{\circ} \mathrm{C}$. The experimental data from this dissolution process were analyzed using homogeneous and heterogeneous kinetic models, and the leaching kinetics of the microwave-dehydrated ulexite waste were defined. The activation energy of the oxalic acid solution of the microwave-dehydrated ulexite waste was also calculated.
\end{abstract}

\section{Key Words}

"Boric acid, microwave-dehydrated ulexite waste, dissolution, leaching kinetics, activation energy" 


\section{Introduction}

The commercially produced boron minerals are colemanite, ulexite and tincal. Ulexite is produced in large quantities in Balikesir, Turkey (Bayca 2009). It is a sodium-calcium borate mineral with a chemical composition of $\mathrm{NaCaB}_{5} \mathrm{O}_{9} \cdot 8 \mathrm{H}_{2} \mathrm{O}$, theoretically containing $42.95 \% \mathrm{~B}_{2} \mathrm{O}_{3}$. The water in the structure of ulexite exists as 3 moles of hydroxyl groups and 5 moles of crystal water $\left(\mathrm{NaCa}\left[\mathrm{B}_{5} \mathrm{O}_{8}(\mathrm{OH})_{6}\right] .5 \mathrm{H}_{2} \mathrm{O}\right)$. Ulexite exists as a white parallel fiber has a triclinic crystal structure and it has relatively low water solubility, \% 0.5 at $25^{\circ} \mathrm{C}$ (Brotherton 1995 , Gerhartz 1985).

Crystalline boric acid has a molecular weight of $61.83 \mathrm{~g} / \mathrm{mol}$ and a boron oxide content of $56.36 \%$, a density of $1.517 \mathrm{~g} / \mathrm{cm}^{3}$ with a chemical formula of $\mathrm{H}_{3} \mathrm{BO}_{3}, \mathrm{HBO}_{3}$ or $\mathrm{B}_{2} \mathrm{O}_{3} .3 \mathrm{H}_{2} \mathrm{O}$ with a melting point of $170.9^{\circ} \mathrm{C}$ and a crystal structure of the triclinic. It is available in 3 types: orthoboric acid, metaboric acid and tetra boric acid. Boric acid is used as reducing the expansion coefficient of glass to prevent cracking and breaking of glass materials against heat. Boric acid is a glass-forming agent and aids in fiber formation by reducing the viscosity of the melt. Boric acid is used in two opposite locations as micronutrients in low concentrations fertilizers and as plant killers in high concentrations (Roskill, 1999; Smith, 1992).

Studies have been made of the dissolution of ulexite in ammonium nitrate (Demirkiran et al. 2009), phosphoric acid (Dogan and Yartasi, 2009), citric acid (Ekmekyapar et al., 2012), water saturated $\mathrm{SO}_{2}$ (Alkan and kocakerim, 1987), ammonia solutions saturated with $\mathrm{CO}_{2}$ (Kunkul et al, 1997), EDTA (Alkan et al, 2000), sulphuric acid (Tunc et al, 1999), thermally dehydrated ulexite in sulphuric acid solution (Kunkul et al., 1997) and acetic acid (Kunkul et al. 1999) were studied.

\section{Heating Theory}

In conventional heating methods, heat is transmitted from the surface of the material to its center. Compared to these methods, since the heat is produced in the material during microwave heating, the heating speed is high and the processing time is short.

\subsection{Conventional heating}

In conventional heating, warming starts from the surface of the material and heat advances towards the center of the material. Therefore, at the start of heating, the temperature of the interior of the material is low although the material surface is hot. The material must be heated for a long time to ensure that the temperature of the center of the material and the surface of the material are the same. In the conventional heating process, heat transfer in the material is carried out by conduction and convection. In conventional heating process, it is directly proportional to the heat conduction coefficient of the material. If the heat transfer coefficient of the material is high, the heating time of the material is shortened.

\subsection{Microwave heating}

Microwaves are non-ionizing electromagnetic waves that cover a certain portion of the electromagnetic spectrum within the wavelength of $1 \mathrm{~mm}-1 \mathrm{~m}$ and the frequency range $300 \mathrm{MHz}-300 \mathrm{GHz}$. The basis of microwave heating is based on the fact that the dielectric material absorbs microwave energy and converts it into heat energy. Microwave heating as dielectric constant and dielectric loss factor are explained by two concepts. The dielectric constant $\left(\varepsilon^{\prime}\right)$ is indicative of the ability of a material showing dielectric properties to absorb microwave energy. The dielectric loss factor ( $\varepsilon$ ") is defined as the ability to convert microwave energy absorbed by a material into heat. The loss factor is the loss of energy that microwave energy passes through a material. The higher the loss factor, the faster the material heats up with microwave energy. Depending on the temperature of the material, chemical composition, physical condition and frequency of electromagnetic waves, the loss factor value may vary. There is also a missing tangent $(\tan \delta$ ) value. Dipole moment refers to the electrical charge between the poles of molecules with electrical polarity. Dipole moment materials (eg water molecule) produce heat when exposed to microwave. The dipole-moment molecules exposed to the electric field of the microwave are aligned with the applied field as a result of the rotational movement. As a result of the frictional force caused by this rotational movement, the molecules gain energy and warm up. Domestic microwave ovens operate at a frequency of $2.45 \mathrm{GHz}$ because they absorb water molecules very well. Molecules of a substance absorbed in a microwave oven at this frequency vibrate 2.5-3 billion times per second to gain kinetic energy, so that the material heats up (Banik et al., 2003; George et al., 1991; Siguemoto et al., 2016; Guo et al., 2011).

The duration of the microwave heating process depends on the water content, density, mass, dielectric constant and ion charge of the material to be heated. In addition to these factors, microwave heating also affects other parameters such as operating frequency, power, thermal conductivity properties and specific temperature of the microwave. As a microwave-heated material is hotter than the inside, it creates cracks in the water depending on the strength of the material as it evaporates. Thanks to this effect, microwave energy is also used in mining to increase the degradability of ores by forming cracks in the material before grinding and increasing existing cracks (Gungoren et al., 2016; Demir et al., 2017; Vorster, 2001; Al-Harahsheh ve Kingman, 2004).

In this study, it was aimed to investigate the production of boric acid from microwave-dehydrated ulexite waste by leaching with oxalic acid solution. Furthermore, dissolution kinetics of ulexite waste dehydrated by microwave heating in oxalic acid solutions was studied. Homogeneous and heterogeneous models were examined to detect kinetics of the solubility of microwave-dehydrated ulexite waste in oxalic acid solutions. The activation energy of the leaching of the microwave-dehydrated ulexite in the oxalic acid solutions waste was calculated. 


\section{Materials and method}

Ulexite waste material was provided by Etimine Bigadic Boron Works in Turkey. It was dried at room temperature, and the sample was ground in a mortar and sieved through a $500 \mu \mathrm{m}$ sieve. Grinding continued until the oversize was $1 \%$.

$3 \mathrm{~g}$ of weighed under-sieve ulexite waste sample was placed on porcelain crucible. Crucible was heated in a household microwave oven at $700 \mathrm{~W}$ for 20 minutes. The temperature of the ulexite waste heated in the microwave was measured using an infrared thermometer.

The methyl red, D-mannitol, sodium hydroxide, oxalic acid, and phenolphthalein reagents were provided from $\mathrm{Merck}$ The $\mathrm{B}_{2} \mathrm{O}_{3}$ content of the liquid phase was examined by the Koklu et al. (2003) titration procedure.

In a typical experiment, a three-necked flask connected to a spiral condenser on a neck was placed in a solution of sulfuric acid and heated in a water bath at a specified temperature. When this solution temperature reached the desired temperature, weighed calcined ulexite waste was added to this solution. This solution was stirred at $500 \mathrm{rpm}$ stirring speed for 30 minutes. At the end of this time, this solution was filtered on filter paper. The filtration filtrate was heated to $35^{\circ} \mathrm{C}$ to obtain boric acid crystals.

\section{Results}

In the chemical analysis of the ulexite waste, it was determined that it contained high amounts of boron oxide, with $27.87 \% \mathrm{CaO}$, $21.83 \% \mathrm{~B}_{2} \mathrm{O}_{3}$, and $10.7 \% \mathrm{SiO}_{2}$. Table 1 shows the chemical analysis of the ulexite waste.

Table 1. Chemical analysis of ulexite waste

\begin{tabular}{llllllllll}
\hline Compounds & $\mathrm{CaO}$ & $\mathrm{B}_{2} \mathrm{O}_{3}$ & $\mathrm{SiO}_{2}$ & $\mathrm{MgO}$ & $\mathrm{SrO}$ & $\mathrm{Na}_{2} \mathrm{O}$ & $\mathrm{Fe}_{2} \mathrm{O}_{3}$ & $\mathrm{Al}_{2} \mathrm{O}_{3}$ & $\mathrm{KK}$ \\
\hline Percent & 27.87 & 21.83 & 10.74 & 3.72 & 3.01 & 2.11 & 0.33 & 0.18 & 30.21 \\
\hline
\end{tabular}

In the XRD analysis of ulexite waste, major minerals were found to contain ulexite, colemanite, dolomite, calcite, quartz, minerals. Ulexite waste contains two boron minerals as major. These are $27.87 \%$ ulexite and $19.65 \%$ colemanite.

\subsection{Microwave-dehydration}

$500 \mu \mathrm{m}$ of undersize ulexite waste was heated in the microwave domestic oven for 20 minutes. The temperature of the ulexite waste reached to $295^{\circ} \mathrm{C}$ by microwave heating at $700 \mathrm{~W}$ power. Eymir et al. (2005) reported that calcination of ulexite by microwave heating has reached a power of $600 \mathrm{~W}$ and a temperature of $295^{\circ} \mathrm{C}$.

The following reaction can occur as a result of heating the ulexite mineral in the ulexite waste sample by microwave (Eq 1).

$$
\mathrm{NaCaB}_{5} \mathrm{O}_{9} \cdot 8 \mathrm{H}_{2} \mathrm{O}_{(\mathrm{s})}+\text { heat }=\mathrm{NaCaB}_{5} \mathrm{O}_{9} \cdot \mathrm{nH}_{2} \mathrm{O}_{(\mathrm{s})}+(8-\mathrm{n}) \mathrm{H}_{2} \mathrm{O}_{(\mathrm{l})}
$$

As a result of heating by microwave, the ulexite mineral becomes dehydrated and loses some of its crystal water.

The following reaction can occur as a result of heating the colemanite mineral in the ulexite waste sample by microwave (Eq 2).

$$
\mathrm{Ca}_{2} \mathrm{~B}_{6} \mathrm{O}_{11} \cdot 5 \mathrm{H}_{2} \mathrm{O}_{(\mathrm{s})}+\text { heat }=\mathrm{Ca}_{2} \mathrm{~B}_{6} \mathrm{O}_{11} \cdot \mathrm{nH}_{2} \mathrm{O}_{(\mathrm{s})}+(5-\mathrm{n}) \mathrm{H}_{2} \mathrm{O}_{(\mathrm{l})}
$$

As a result of microwave heating, the colemanite mineral dehydrates and loses some of the crystal water.

The original ulexite waste was $21.83 \% \mathrm{~B}_{2} \mathrm{O}_{3}$, while the microwave-dehydrated sample contained $29.04 \% \mathrm{~B}_{2} \mathrm{O}_{3}$. A $33.03 \%$ increase in $\mathrm{B}_{2} \mathrm{O}_{3}$ content was observed when the ulexite waste was dehydrated in the microwave oven. This increase can be attributed to a portion of the crystal water of the ulexite, which is dehydrated in the microwave oven.

\subsection{Dissolution reactions}

The dissolution reaction of the microwave-dehydrated ulexite waste in oxalic acid solutions is given below. The following reactions can occur as a result of the leaching of the ulexite mineral present in the microwave dehydrated ulexite waste sample in the oxalic acid solution (Eq 5).

$$
2\left(\mathrm{NaCaB}_{5} \mathrm{O}_{9} .8 \mathrm{H}_{2} \mathrm{O}_{(\mathrm{s})}\right)+3 \mathrm{C}_{2} \mathrm{H}_{2} \mathrm{O}_{4(\mathrm{aq})}+2 \mathrm{H}_{2} \mathrm{O}=10 \mathrm{H}_{3} \mathrm{BO}_{3(\mathrm{aq})}+2 \mathrm{CaC}_{2} \mathrm{O}_{4(\mathrm{~s})}+2 \mathrm{Na}^{+}{ }_{(\mathrm{aq})}+\mathrm{C}_{2} \mathrm{O}_{4}{ }^{2-}{ }_{(\mathrm{aq})}+6 \mathrm{H}_{2} \mathrm{O}_{(\mathrm{l})}
$$

The following reactions can occur as a result of the leaching of the ulexite mineral present in the microwave-dehydrated colemanite waste sample in the oxalic acid solution (Eq 6). 


$$
\mathrm{Ca}_{2} \mathrm{~B}_{6} \mathrm{O}_{11} .5 \mathrm{H}_{2} \mathrm{O}_{(\mathrm{s})}+3 \mathrm{C}_{2} \mathrm{H}_{2} \mathrm{O}_{4(\mathrm{aq})}+2 \mathrm{H}_{2} \mathrm{O}=10 \mathrm{H}_{3} \mathrm{BO}_{3(\mathrm{aq})}+2 \mathrm{CaC}_{2} \mathrm{O}_{4(\mathrm{~s})}+6 \mathrm{H}_{2} \mathrm{O}_{(\mathrm{l})}
$$

The leaching of microwave-dehydrated ulexite waste in oxalic acid solution concluded in boric acid, calcium sodium and oxalate microwave-dehydrated ulexite waste leached in a hot oxalic acid solution and a leach solution was obtained. Liquid and solid phases were separated by filtering the leach solution. The white boric acid crystals precipitated when the liquid phase was cooled.

\subsection{Influence of temperature on leaching efficiency}

In order to define the influence of temperature on the acid leaching process of the microwave-dehydrated ulexite waste, the process was examined at temperatures of $25,40,50,60$ and $70^{\circ} \mathrm{C}$.

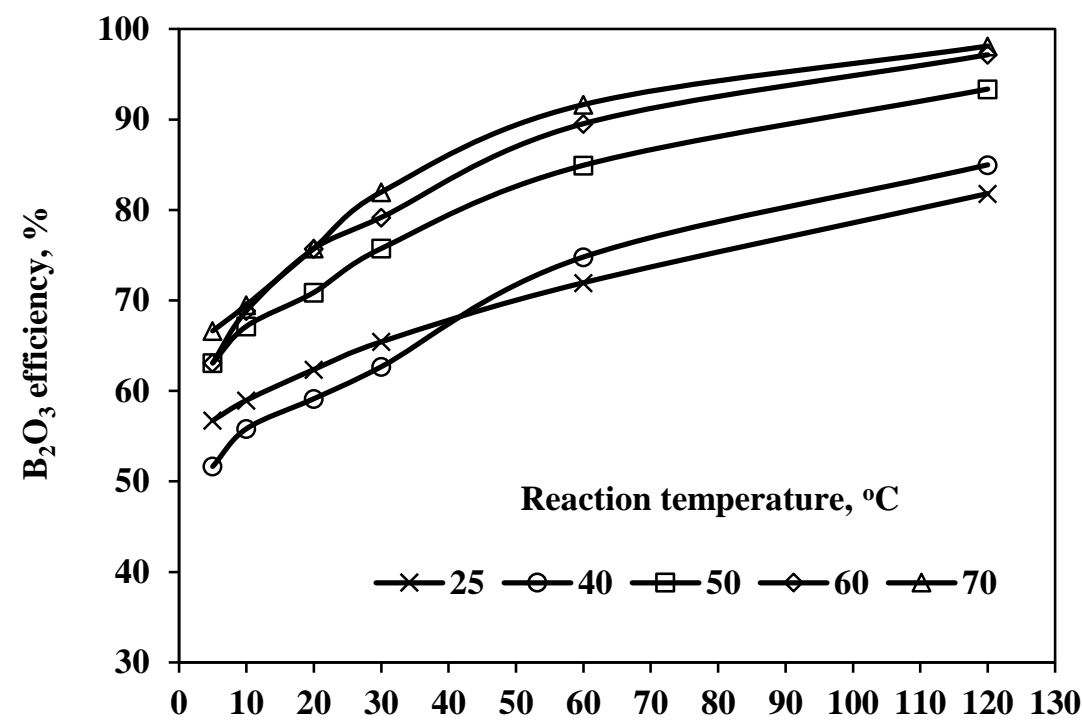

Leaching time, min.

Figure 1. Influence of temperature on leaching of microwave-hydrated ulexite waste

The constant parameters of the leaching experiments were a stirring speed of $200 \mathrm{rpm}$, a solid-liquid ratio of $1 \%$ and an acid concentration of $4 \%$. The findings are seen in Figure 1.

At a constant temperature of $25^{\circ} \mathrm{C}$, the leaching efficiency increased from $56.73 \%$ to $81.80 \% \mathrm{~B}_{2} \mathrm{O}_{3}$ as the leaching time increased from 10 to 120 minutes. As an increment in the leaching time between 10 and 120 minutes was observed at a constant temperature of $70^{\circ} \mathrm{C}$, the leaching efficiency started at $66.63 \%$ and reached $98.11 \% \mathrm{~B}_{2} \mathrm{O}_{3}$. When the reaction temperature was increased from $25^{\circ} \mathrm{C}$ to $70^{\circ} \mathrm{C}$, the leaching efficiency of $\mathrm{B}_{2} \mathrm{O}_{3}$ increased from $56.73 \%$ to $98.11 \% \mathrm{~B}_{2} \mathrm{O}_{3}$.

\subsection{Kinetic analysis}

Reaction rates are explained as heterogeneous or homogeneous reaction in a liquid-solid reaction system. In homogeneous reactions, all reacting materials are present in a single phase.

The kinetics of a first order homogenous reaction control model is shown by the following equation.

$$
k t=-\ln (1-X)
$$

The kinetics of a second order homogenous reaction control model is shown by the following equation.

$$
k t=\left[X(1-X)^{-1}\right]
$$

where $k$ is the reaction rate constant $\left(\mathrm{min}^{-1}\right), t$ is the time (min), and $X$ is the fraction reacted (Levenspiel, 1999).

The dissolution kinetics of the microwave-dehydrated ulexite waste in the oxalic acid solutions were analyzed by homogeneous and heterogeneous kinetic models. Heterogeneous kinetic models did not conform to the dissolution reaction in the oxalic acid solutions of the microwave-dehydrated ulexite waste. According to these results, it was determined that the kinetics of dissolution in the oxalic acid solutions of microwave-dehydrated ulexite waste matched the first degree homogeneous kinetic model. The graph of dissolution of the microwave-dehydrated ulexite waste in the oxalic acid solution is given in Figure 2. 


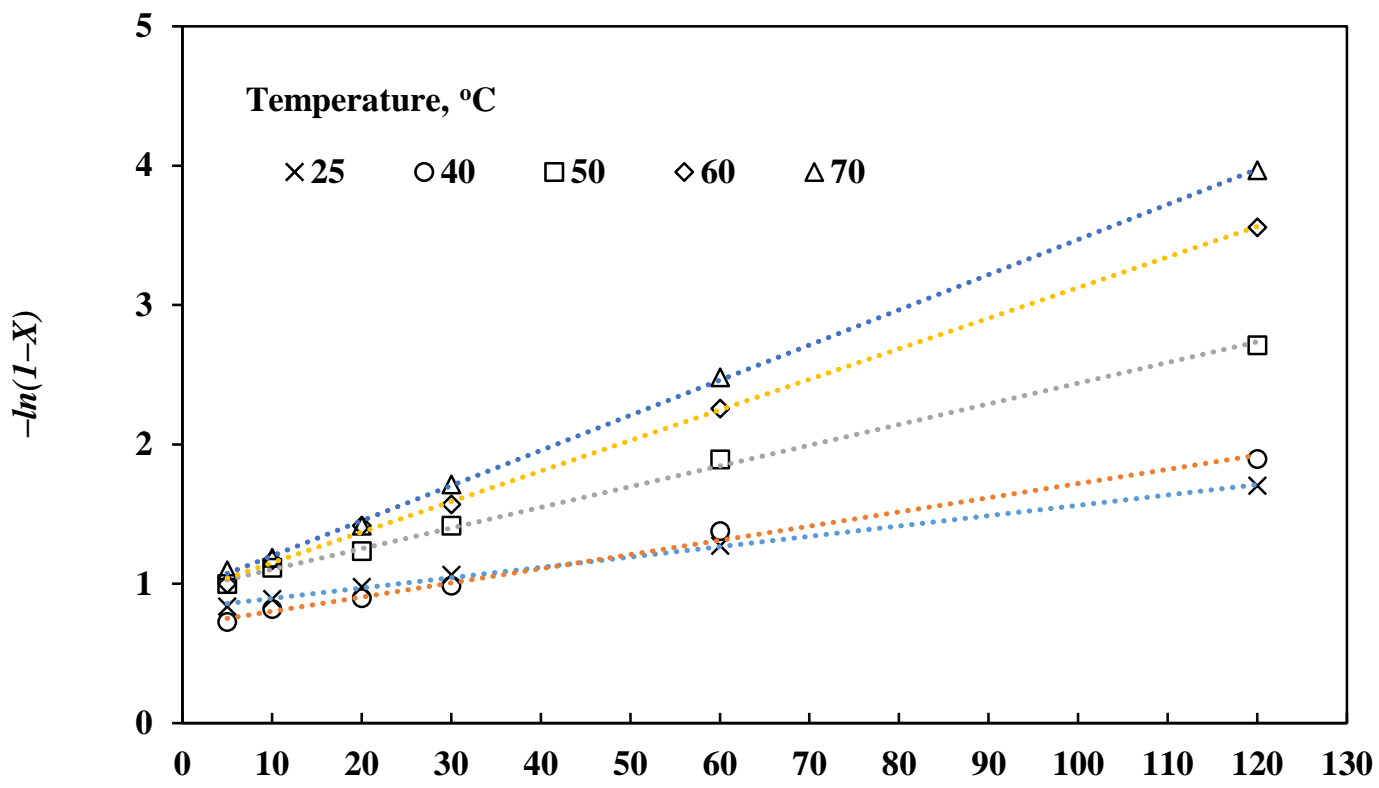

Leaching time, min.

Figure 2. Variation of $-\ln (1-X)$ versus time.

To calculate the activation energy of the leaching reaction, the Arrhenius graph was plotted using the data in Figure 2. Using the results shown in Figure 2, a graph was plotted lnk against $1 / T$ and Figure 3 was obtained. The energy of microwave-dehydrated ulexite waste in oxalic acid solutions was calculated from the inclination of the Arrhenius graph by $25.04 \mathrm{~kJ} / \mathrm{mol}$. The $k$ value increased as a result of increasing temperature. In other words, the reaction rate increased with increasing temperature.

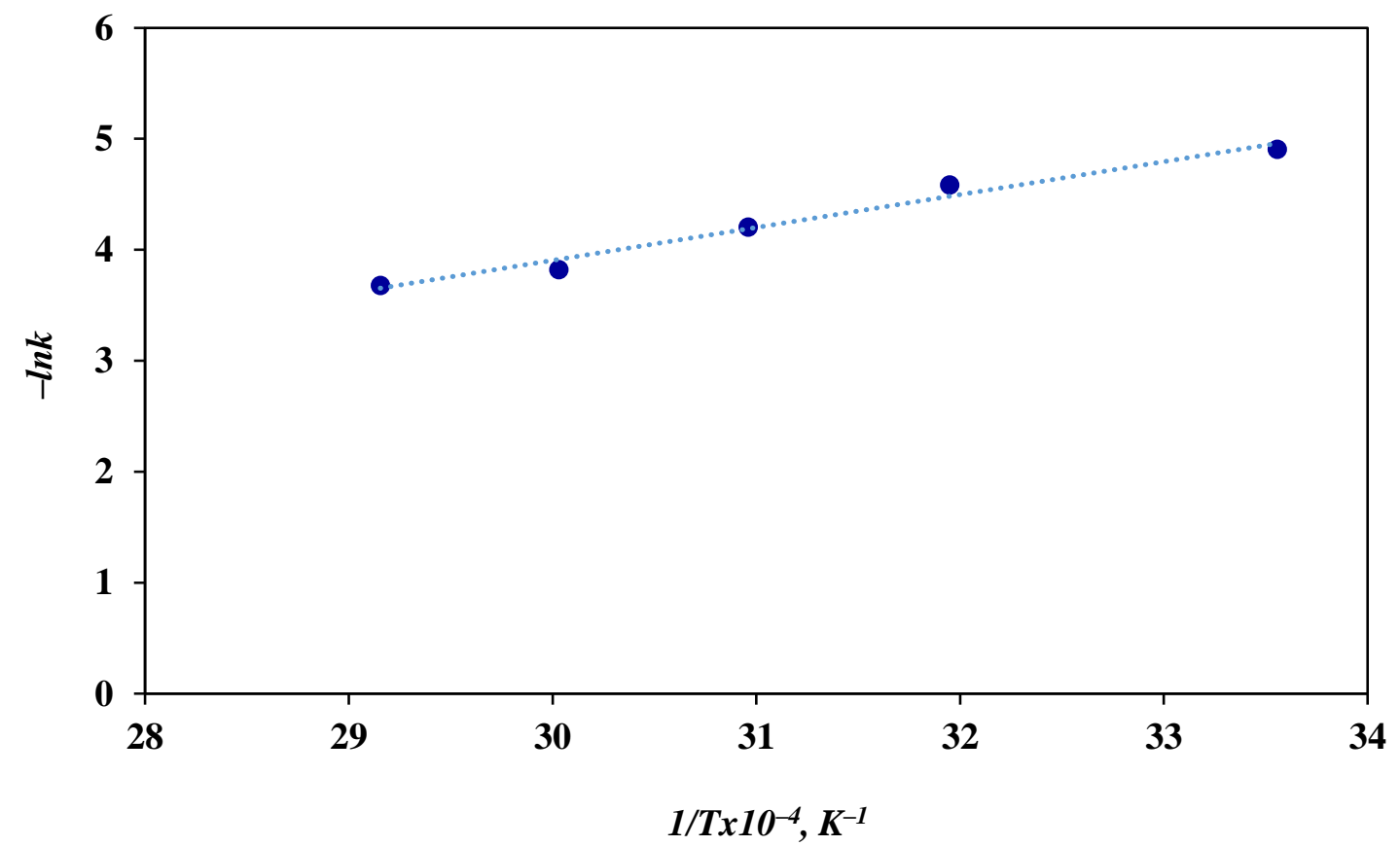

Figure 3. Arrhenius graph of dissolution of microwave-hydrated ulexite waste in oxalic acid solutions

\section{Discussions}

Bayca et al (2014) studied the dissolution of ulexite in oxalic acid solutions. The dissolution rate of ulexite waste increased with increasing temperature and stirring rate. Stirring rate had very little effect on dissolution rate in a dissolution time of 120 minutes. As a result of the dissolution of ulexite in oxalic acid solution, boric acid and sodium oxalate were formed in the liquid phase, while calcium oxalate, magnesium oxalate and quartz were formed in the solid phase. Pure boric acid crystals with cooled liquid phase were obtained. The kinetic model of the dissolution process was determined to be a first-order reaction control model. The activation energy was found to be $41.09 \mathrm{~kJ} / \mathrm{mol}$. 
In this study, the production of boric acid from microwave dehydrated ulexite waste by leaching oxalic acid solution was investigated. Ulexite waste was heated in a $700 \mathrm{~W}$ domestic microwave oven for 20 minutes. The temperature of the ulexite waste increased to $295^{\circ} \mathrm{C}$ after this time. Ulexite mineral contains sodium calcium borate and 8 moles of crystal water. As a result of microwave calcination, most of the crystal water in the ulexite has evaporated. While the grade of ulexite waste was $21.83 \% \mathrm{~B}_{2} \mathrm{O}_{3}$, the result of microwave heating increased to $29.04 \% \mathrm{~B}_{2} \mathrm{O}_{3}$. This microwave calcination resulted in a $33.03 \%$ increase in the boron oxide content of the ulexite waste. The activation energy required for dissolution of ulexite waste in oxalic acid solution is 41 $\mathrm{kJ} / \mathrm{mol}$, while the activation energy required for dissolution of microwave dehydrated ulexite waste in oxalic acid solutions is 25.04 $\mathrm{kJ} / \mathrm{mol}$. Microcracks and porosities formed by calcination of ulexite increase the contact of leaching reagent (oxalic acid solution) with the particles. Increased contact of the leaching reagent with the ulexite particle may increase the rate of dissolution of the ulexite. These results are consistent with the literature. Ulexite exfoliates as a result of gradual water vapour removal, and the structure becomes amorphous with numerous microcracks and interstices (Sener et al., 2000).

As a result of this study, the filtrate of the leach solution was crystallized. These crystal particles were found to be boric acid crystals containing $56.2 \% \mathrm{~B}_{2} \mathrm{O}_{3}$.

\section{Conclusions}

In XRD analysis, ulexite wastes were found to contain the major minerals ulexite, colemanite, dolomite, calcite and quartz. Chemical analysis showed that ulexite wastes contained $21.8 \% \mathrm{~B}_{2} \mathrm{O}_{3}$ boron oxide. The solubility of microwave-dehydrated ulexite waste in oxalic acid solutions increased with increasing temperature. The leaching efficiency of microwave-dehydrated ulexite waste in oxalic acid solutions was $98.11 \%$. It was determined that the leaching kinetics of the oxalic acid solutions of the microwave-hydrated ulexite waste matched the first order homogeneous kinetic model. The activation energy of the leaching of the microwave-dehydrated ulexite waste in oxalic acid solutions was figured out to be $25.04 \mathrm{~kJ} / \mathrm{mol}$. Optimum conditions for boric acid production were a stirring speed of $200 \mathrm{rpm}$, a solid-liquid ratio of $1 \%$, an acid concentration of $4 \%$ and a reaction temperature of $70^{\circ} \mathrm{C}$.

\section{References}

Al-Harahsheh, M., Kingman, S.W. (2004). Microwaveassisted leaching-a review. Hydrometallurgy, 73 (3-4), $189-203$.

Alkan, M., Cifci, C., Ayaz, F. Dogan, M. (2000). Dissolution kinetics of ulexite in aqueous EDTA solutions. Canadian Metallurgical Quarterly, 39, 433-440.

Alkan, M., Kocakerim, M.M. (1987). Dissolution Kinetics of Ulexite in Water Saturated by Sulphurdioxide. Journal of Chemical Technology and Biotechnology. 40, 215-222,

Banik, S., Bandyopadhyay, S. and Ganguly, S. (2003). Bioeffects of microwave-a brief review. Bioresource Technol, 87, $155-159$.

Bayca, S.U. (2009). Effects of the addition of ulexite to the sintering behavior of a ceramic body. Journal of Ceramic Processing Research, 10, 162-166.

Bayca, S.U., Kocan, F. Abali, Y. (2014). Investigation of Leaching Kinetics of Ulexite Waste in Oxalic Acid Solutions. Chemical and Biochemical Engineering Quarterly, 28 (3) 273-280.

Brotherton, R.J. (1995). Encyclopedia of Inorganic Chemistry, Wiley, New York, USA, 363-367.

Demir, I., Güngören, C., Özkan, Ş.G. (2017). Mikrodalga enerjisinin kolemanit cevherinin ufalanmasına ve flotasyonuna etkisi, Boron, 2, $75-81$.

Demirkiran, N. (2009). Dissolution kinetics of ulexite in ammonium nitrate solutions. Hydrometallurgy, 95, $198-202$.

Dogan T., Yartasi, A. (2009). Kinetic investigation of reaction between ulexite ore and phosphoric acid. Hydrometallurgy, 96, 294299.

Ekmekyapar, A., Kunkul, A., Demirkiran N. (2012). Kinetic Investigation of Reaction Between Mineral Ulexite and Citric Acid. Mineral Processing and Extractive Metallurgy Review, 31, 250 - 255.

Eymir, C., Okur, H. (2005). Dehydration of Ulexite By Microwave Heating, Thermochimica Acta, 428, 125-129.

Gerhartz, W. (1985). Ullmann's Encyclopedia of Industrial Chemistry, Wiley, Germany, A4, p. 263, 272, $274,275$.

George, R.M. and Burnett, S.A. (1991). General guidelines for microwaveable products. Food Control, 2 (1), 35 -44. 
Gungoren, C., S.G., Ozkan, Hacifazlioglu, H. (2016). Mikrodalga kurutmanın linyit kömürünün öğütülebilirliğine etkisi, Bilimsel madencilik dergisi, 55, $15-22$.

Guo, W., Liu, Y., Zhu, X. and Wang, S. (2011). Temperature-dependet dielectric properties of honey associated with dielectric heating. Journal of Food Engineering, 102, 209-216.

Koklu, M., Ozyetis, O., Maraslioglu, D., Yavuklu E., Celen, B., Tufan T., Gunduz, M. (2003). Developments in analyzes of calcium borate. (in Turkish), 18 International Mining Congress and Exhibition of Turkey, 10 - 13 June, Antalya, pp. 141 - 146.

Kunkul, A., Yapici, S., Kocakerim, M.M., Copur, M. (1997). The dissolution kinetics of ulexite in ammonia solutions saturated with $\mathrm{CO}_{2}$. Hydrometallurgy, 44, 135-145.

Kunkul, A., Tunc, M., Yapici, S., Ersahan, H., Kocakerim, M.M. (1997). Dissolution of thermally dehydrated ulexite in sulphuric acid solution. Industrial \& Engineering Chemistry Research, 36, 4847-4851.

Levenspiel O. (1999). Chemical Reaction Engineering, New York, John Wiley and Sons.

Roskill, 1999, The Economics of Boron, roskill Information Services Ltd, london England.

Sener, S. Ozbayoglu, G. Demirci, S. (2000). Changes in the structure of ulexite on heating, Thermochim. Acta 362, 107-112.

Siguemoto, E.S. and Gut, J.A.W. (2016). Dielectric properties of cloudy apple juices relevant to microwave pasteurization. Food Bioprocess Technology, 9, $1345-1357$.

Smith, R.A., McBroom, R.B. (1992). Boron Compouns, Kirk othmer Encyclopedia of Chemical Technology vol 4, New York, John Wiley and Sons.

Tunc, M., Kocakerim, M.M., Yapici, S., Bayrakceken, S. (1999). Dissolution mechanism of ulexite in $\mathrm{H}_{2} \mathrm{SO}_{4}$ solution. Hydrometallurgy, 51, 359-370.

Vorster, W. (2001). The effect of microwave radiation on mineral processing. The University of Birmingham, Birmingham, p. 256. 